\title{
INTERNATIONAL \&
} COMPARATIVE

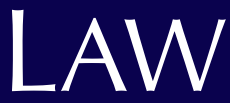

QUARTERLY

\section{VOLUME 69}

\section{PART 4}

\section{OCTOBER 2020}

\section{ARTICLES}

Conflicting Forum-Selection Agreements in Treaty and Contract

Stephen Donnelly

Implementing Human Rights Due Diligence Through Corporate Civil Liability

Artificial Intelligence and the Limits of Legal Personality

Nicolas Bueno and Claire Bright

Simon Chesterman

The Compatibility of Autonomous Weapons with the Principle of

Distinction in the Law of Armed Conflict

Elliot Winter

Foreign Investors' Responsibilities and Contributory

Fault In Investment Arbitration

Jean-Michel Marcoux and Andrea K Bjorklund

Reconciling International Investment Law and

European Union Law in the Wake of Achmea

David Restrepo Amariles, Amir Ardelan Farhadi and Arnaud Van Waeyenberge

The International Endorsement of Corporate Settlements in

Foreign Bribery Cases

Radha Ivory and Tina Søreide

\section{SHORTER ARTICLES}

Recent Developments Under the Brussels I Regulation

Equal Treatment of Parties in International Commercial Arbitration

Trevor C Hartley

llias Bantekas

Combatting or Enabling Domestic Violence? Evaluating the Residence

Rights of Migrant Victims of Domestic Violence in Europe

BOOK REVIEWS 
BICL

\section{British Institute of International and Comparative Law}

The British Institute of International and Comparative Law $(\mathrm{BIICL})$ is a leading independent legal research and membership organisation with charitable status, unaffiliated to any university. It is the only body of its kind in the UK and one of very few in the world. It is not publicly or privately funded by any one government, institution or person. Established in 1958 and based in London with a dedicated team of staff, it brings together legal practitioners in private and public practice, in-house counsel, scholars and students, as members and contributors. It has developed a strong global network in international and comparative law and the rule of law.

BIICL undertakes five key activities: applied legal research, events, capacity-building training, publications and membership services. We conduct research around the world across the broad range of public international law, private international law, comparative law, competition law, European law and international investment law and the rule of law. Our focus is on applied research, based on strong conceptual foundations, which is practical, offers examples of good practice, and recommendations for policy and legal actions. Our activities often cross the traditional boundaries of law, so as to engage with contemporary national, regional and international issues, and we consistently have an impact on law and policy worldwide.

BIICL has created a diverse community of scholars and practitioners and serves as an unrivalled focal point for our substantial membership base. BIICL members include judges, practising lawyers, government officials, regulators, international civil servants, academics and students. We keep our members abreast of the latest developments in international and comparative law.

Within BIICL, the Bingham Centre for the Rule of Law is devoted to the study and promotion of the rule of law worldwide. Launched in 2010, the Centre has established a broad base of work internationally that highlights threats to the rule of law while promoting high quality studies and training. 


\section{INSTRUCTIONS FOR CONTRIBUTORS}

The ICLQ welcomes the submission of contributions for consideration by the Board of Editors with a view to publication. All manuscripts must be submitted online via the website: http://mc.manuscriptcentral.com/icla

The Board of Editors will only consider material which complies with the following:

1. The submission should be an original, unpublished work not currently under consideration for publication elsewhere. Please note that our exclusive submission policy means you cannot submit your work to another journal until you have received a decision from us. If you would like to submit to another journal, you must withdraw your article from consideration by the ICLQ.

2. The ICLQ publishes articles that deal with public international law, private international law, comparative law, human rights law and European Union law. It particularly encourages the submission of innovative and original articles whose theme or content illuminate more than one of these subject areas. Articles which do no more than rehearse familiar and well-known material, or which are concerned only with national law (other than private international law) in a non-comparative way, should not be submitted.

3. Long articles should not exceed 12,000 words $(16,000$ words including footnotes). Pieces of up to 6,000 words (including footnotes) will usually be considered for the 'Shorter Articles' section. The editors will decide on the section to which all contributions, irrespective of length, are best suited should they be accepted for publication. ScholarOne will require you to enter the word count (including footnotes) when submitting your article, and to indicate if you intend it for the 'Shorter Articles and Notes' section.

4. Footnotes should be numbered consecutively throughout the article and be in the form normally used by the ICLQ. Please see the Style Guide for further information. Footnoting should not be excessive.

5. A short (50-100 words) abstract of the article should be supplied. We reserve the right to edit abstracts for length and style. Please also supply a minimum of five keywords (maximum ten) for your article to enable digital searching.

6. Authors should state their present academic or professional affiliation and indicate any professional or personal involvement in the subject matter of the article.

7. The ICLQ only accepts submissions online via the ScholarOne platform. To upload your manuscript please go to: http://mc.manuscriptcentral.com/ iclq. Detailed instructions for submitting your manuscript online can be found at the submission website by clicking on the 'Instructions and Forms' link in the top right of the screen; and then clicking on the 'Author Submission Instructions' icon on the following page. The Editor will acknowledge receipt 
of the manuscript, with a reference number, which should be quoted in all correspondence.

For the ICLQ Style Guide, please visit www.journals.cambridge.org/iclq/ifc. In all matters not included in this Guide, the ICLQ follows the OSCOLA citation system for house style; please visit www.law.ox.ac.uk for details.

\section{SUBSCRIPTIONS}

Subscriptions, orders, and enquiries should be sent to Cambridge University Press, University Printing House, Shaftesbury Road, Cambridge, CB2 8BS, UK, email: journals@cambridge.org. Current prices can be found at https://www. cambridge.org/core/journals/international-and-comparative-law-quarterly/ subscribe. Back issues of all volumes are now available at the current cover price. For more information on the journal see https://www.cambridge.org/ core/journals/international-and-comparative-law-quarterly.

The views expressed in the contributions to this journal are those of their author(s) and do not necessarily reflect the views either of the board of editors of the journal or of the British Institute of International and Comparative Law (BIICL). BIICL is a registered charity and an independent research institute committed to supporting high standards of scholarship in all aspects of international and comparative law.

The ICLQ has been selected for coverage in Clarivate's products and services. The journal is indexed and abstracted in the Social Sciences Citation Index, the Journals Citation Reports/Social Sciences Edition and Current Contents/Social and Behavioural Sciences

\section{PERMISSIONS}

For all matters concerning rights and permissions please contact Cambridge University Press. For more information go to: http://www.cambridge.org/ about-us/rights-permissions

\section{(c) 2020 British Institute of International and Comparative Law}

Printed in the United Kingdom by Bell and Bain Ltd, Glasgow

This journal issue has been printed on FSC-certified paper and cover board. FSC is an independent, non-governmental, not-for-profit organization established to promote the responsible management of the world's forests. Please see www.fsc.org for information.

Authors of accepted articles in International \& Comparative Law Quarterly now have the option to publish on a Gold Open Access basis.

Cambridge Journals Online: For further information about this journal please go to the journal web site at www.cambridge.org/ICLQ 


\section{BIICL GOVERNANCE}

\section{President}

The Rt Hon the Lord Phillips of Worth Matravers KG PC QC

\section{Vice Presidents}

The Rt Hon the Lord Collins of Mapesbury

The Rt Hon Sir David Edward KCMG

Sir Christopher Greenwood GBE CMG QC

\section{Director}

Professor Spyros Maniatis

\section{Board of Trustees}

\section{Chair:}

Keith Ruddock

Professor Dapo Akande

Professor John Bell QC (hon) FBA FRSA

Sonya Branch

Professor Malik Dahlan

Shaheed Fatima QC

Philip Haberman

The Rt Hon Lord Lloyd-Jones

Sir lain Macleod KCMG

Professor Kate O'Regan

Nigel Parr

Constantine Partasides QC

Rupert Skilbeck

Diana Wallis

Andrew Whittaker

\section{Advisers to the Board of Trustees}

The Rt Hon Lady Arden of Heswall DBE Martin Paisner CBE

\section{ICLQ EDITORIAL BOARD}

\section{Co-General Editors}

Professor Sir Malcolm Evans KCMG, OBE, University of Bristol

Professor Spyros Maniatis, British Institute of International and Comparative Law

\section{Board Members}

Professor lan Cram, University of Leeds

Professor Paula Giliker, University of Bristol

Professor Christine Gray, University of Cambridge

Professor Andrew Lang, University of Edinburgh

Professor Robert McCorquodale, University of Nottingham

Professor Dominic McGoldrick, University of Nottingham

Dr Louise Merrett, University of Cambridge

Professor Alex Mills, University College London

Professor Katja S Ziegler, University of Leicester

\section{Managing Editor}

Anna Riddell-Roberts BIICL

\section{Book Review Editor}

Professor lan Cram, University of Leeds

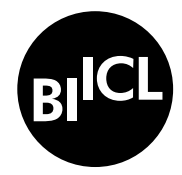

British Institute of International and Comparative Law 


\section{International and Comparative Law Quarterly}

\section{ARTICLES}

Conflicting Forum-Selection Agreements in Treaty and Contract

Implementing Human Rights Due Diligence Through Corporate Civil LIABILITY

Nicolas Bueno and Claire Bright

Artificial Intelligence and the Limits of Legal Personality

Simon Chesterman

The Compatibility of Autonomous Weapons with the Principle of

Distinction in the Law of Armed Conflict Elliot Winter

Foreign Investors' Responsibilities and Contributory Fault in INVESTMENT ARBITRATION

Jean-Michel Marcoux and Andrea K Bjorklund

ReCONCILING InTERnAtional InVESTMENT LAW AND EUROPEAN Union LAW IN THE WAKE OF ACHMEA

David Restrepo Amariles, Amir Ardelan Farhadi and Arnaud Van Waeyenberge

The International Endorsement of Corporate Settlements in Foreign

Bribery CASES

Radha Ivory and Tina Søreide

\section{SHORT ARTICLES}

Recent Developments Under the Brussels i Regulation

Trevor C Hartley

Equal Treatment of Parties in International Commercial Arbitration Ilias Bantekas

Combatting or Enabling Domestic Violence? Evaluating the

Residence Rights of Migrant Victims of Domestic Violence in EUROPE 


\section{BOOK REVIEWS}

Emanuela Fronza, Memory and Punishment: Historical Denialism, Free Speech and the Limits of Criminal Law (Galina Nelaeva and Gulnur Sufiyanova)

Isabel Zuloaga, Reliance in the Breaking-off of Contractual Negotiations: Trust and Expectation in a Comparative Perspective (Ekaterina Pannebakker) 